\title{
Agroecological Factors Correlated to Soil DNA Concentrations of Rhizoctonia in Dryland Wheat Production Zones of Washington State, USA
}

\author{
Patricia A. Okubara, Kurtis L. Schroeder, John T. Abatzoglou, and Timothy C. Paulitz
}

First and fourth authors: United States Department of Agriculture-Agricultural Research Service Root Disease Unit and Biological Control Research Unit, P.O. Box 6430, Pullman, WA 99164-6430; second author: Department of Plant Pathology, Washington State University, Pullman 99164-6430; and third author: Department of Geography, University of Idaho, Moscow 83844-3021.

Accepted for publication 22 January 2014.

\begin{abstract}
Okubara, P. A., Schroeder, K. L., Abatzoglou, J. T., and Paulitz, T. C. 2014. Agroecological factors correlated to soil DNA concentrations of Rhizoctonia in dryland wheat production zones of Washington state, USA. Phytopathology 104:683-691.

The necrotrophic soilborne fungal pathogens Rhizoctonia solani AG8 and $R$. oryzae are principal causal agents of Rhizoctonia root rot and bare patch of wheat in dryland cropping systems of the Pacific Northwest. A 3 -year survey of 33 parcels at 11 growers' sites and 60 trial plots at 12 Washington State University cereal variety test locations was undertaken to understand the distribution of these pathogens. Pathogen DNA concentrations in soils, quantified using real-time polymerase chain reaction, were correlated with precipitation, temperature maxima and minima, and soil texture factors in a pathogen-specific manner. Specifically, $R$. solani AG8 DNA concentration was negatively correlated with precipitation and not correlated with temperature minima, whereas $R$. oryzae concentration
\end{abstract}

ABSTRACT

Rhizoctonia root rot, bare patch, and damping-off have long been recognized as chronic, yield-reducing diseases in smallgrain cereal production systems in the Pacific Northwest (PNW), United States, and Australia (3,12,37). Principal causal agents in the PNW are Rhizoctonia solani Kühn AG8 (teleomorph Thanatephorus cucumeris (A. B. Frank) Donk) and $R$. oryzae Ryker \& Gooch (teleomorph Waitea circinata Warcup \& P. H. B. Talbot) $(17,23,27)$. $R$. solani AG8 is associated with root rot and bare patches in small-grain cereals planted to direct-seeded (notill) fields $(4,24,26)$. Infections of $R$. oryzae cause uneven stand height and, in severe cases, seedling death of wheat and barley $(27,34)$ and can cause symptoms in pea and other legumes $(22)$. $R$. oryzae is often present in the same locations as $R$. solani AG8. Genotype III of $R$. oryzae was abundant and the most virulent of the three genotypes found in the PNW (14,17); hence, it was selected for this survey. Based on internal transcribed sequence (ITS) sequence identities, $R$. oryzae genotype III was most closely related to W. circinata var. circinata (17). Current management of $R$. solani AG8 and $R$. oryzae includes a combination of tillage, fungicide seed treatment, and control of volunteers and weeds

Corresponding author: P. A. Okubara; E-mail address: patricia.okubara@ars.usda.gov

* The $\boldsymbol{e}$-Xtra logo stands for "electronic extra" and indicates that the online version contains one supplemental figure and two supplemental tables.

http://dx.doi.org/10.1094/PHYTO-09-13-0269-R

This article is in the public domain and not copyrightable. It may be freely reprinted with customary crediting of the source. The American Phytopathological Society, 2014. was correlated with temperature minima but not with precipitation. However, both pathogens were more abundant in soils with higher sand and lower clay content. Principal component analysis also indicated that unique groups of meteorological and soil factors were associated with each pathogen. Furthermore, tillage did not affect $R$. oryzae but affected $R$. solani AG8 at $P=0.06$. Lower soil concentrations of $R$. solani AG8 but not $R$. oryzae occurred when the previously planted crop was a broadleaf $(P<0.05)$. Our findings showed that $R$. solani AG8 concentrations were consistent with the general distribution of bare patch symptoms, based on field observations and surveys of other pathogens, but was present at many sites in which bare patch symptoms were not evident. Management of Rhizoctonia root rot and bare patch should account for the likelihood that each pathogen is affected by a unique group of agroecological variables.

Additional keywords: agroclimate zone, direct seed.

between plantings (green bridge control), and is based on the assumption that the pathogens occur as a complex.

The dryland wheat cropping zone of eastern Washington (east of the Cascade Range) encompasses a contiguous area of $>150,000 \mathrm{~km}^{2}$, has been cropped for $>100$ years, and covers a wide range of soil and climatic variations (31) (http://www. wsdot.wa.gov/publications/fulltext/hydraulics/wameanannprecip. pdf). In central Washington, in the rain shadow of the Cascades, annual precipitation is $<200 \mathrm{~mm}$ but increases to $>600 \mathrm{~mm}$ in the eastern part, along the Idaho border (known as the Palouse area). Likewise, there is a west-east gradient of soil texture, with lighter, sandy silt loams in the western arid zone and silt-loams with higher clay content in the eastern section. In addition, the topography in the eastern section is steep, with hills of deep winddeposited silt loams up to $100 \mathrm{~m}$ in height. Finally, there is a general north-south gradient of temperature and a longitudinal west-east decrease in temperature associated with the elevation increase in the Palouse. Because of the precipitation limitations, three general cropping zones can be recognized. The first is the winter wheat-summer fallow zone in the driest areas (150 to $300 \mathrm{~mm}$ of annual precipitation), where a crop is only planted every other year. The fallow year is used to store moisture in the soil profile. Winter wheat is planted in August to September into a moisture zone under a dust mulch, and harvested the following July to August. In the second zone (300 to $400 \mathrm{~mm}$ ), a cereal crop (spring or winter wheat or spring barley) is planted 2 out of 3 years, with a fallow the third year. In the wettest zone (400 to $600 \mathrm{~mm}$ ) a crop is planted every year in a 3-year rotation (winter wheat/spring wheat or spring barley/broadleaf crop. The broadleaf 
crop is usually canola or a grain legume such as pea, lentil or chickpea).

Over the last decade, efforts have been made to identify the major pathogenic Rhizoctonia spp. and understand how species distribution of Rhizoctonia is related to climate and cropping practices in different growing regions. The ultimate goal is to optimize management of Rhizoctonia root rot and bare patch for each growing region. Much of the work was based on culturing fungi from soil and plants using a toothpick baiting assay (25). In the mid 2000s, a real-time quantitative polymerase chain reaction (PCR) method was developed to quantify Rhizoctonia spp. from the soil $(17,32)$. We used this technique in a 3-year survey to quantify soil DNA concentrations of $R$. solani AG8 and $R$. oryzae at variety test locations and grower fields across PNW cropping zones. In addition, we correlated pathogen distributions with the meteorological factors (precipitation and temperature) and soil texture factors to better understand how these abiotic factors shape the geographic distribution of pathogens across this large, diverse cropping region.

\section{MATERIALS AND METHODS}

Sampling sites and sample collection. Soil samples were collected at 33 parcels from 11 grower locations and 60 plots at 22 locations of the Washington State University (WSU) Cereal Variety Testing Program. Growers' parcels ranged in area from 5,600 to $30,000 \mathrm{~m}^{2}$, and variety test plots were $\approx 2,000$ to 3,000 $\mathrm{m}^{2}$. Soils were collected from the end of April through mid-June, depending upon the soil moisture at each site. Global Positioning System (GPS) coordinates for growers' parcels were determined in the first year of sampling using an AGGPS 332 GPS receiver (Trimble Navigation Ltd., Sunnyvale, CA); these coordinates were used in the two subsequent years. GPS coordinates of the variety test plots, which moved from year to year, were obtained using Google Earth (9). Soil cores $(2.5 \mathrm{~cm}$ in diameter by $15 \mathrm{~cm}$ deep) were obtained from the root zone in the seeded row. Samples from grower parcels consisted of five cores taken along each of three parallel transects per parcel (Fig. 1A). Samples from cereal variety test plots consisted of five cores from each of five diagonal transects per plot (Fig. 1B). The five cores from each transect were pooled, constituting one subsample. The less intensive sampling (fewer samples per unit area) at growers' parcels was mainly due to the economics of sample processing. In total, 582 samples were obtained from soil collections carried out in 2006,2007 , and 2008 . Soil samples were stored at $4^{\circ} \mathrm{C}$ prior to

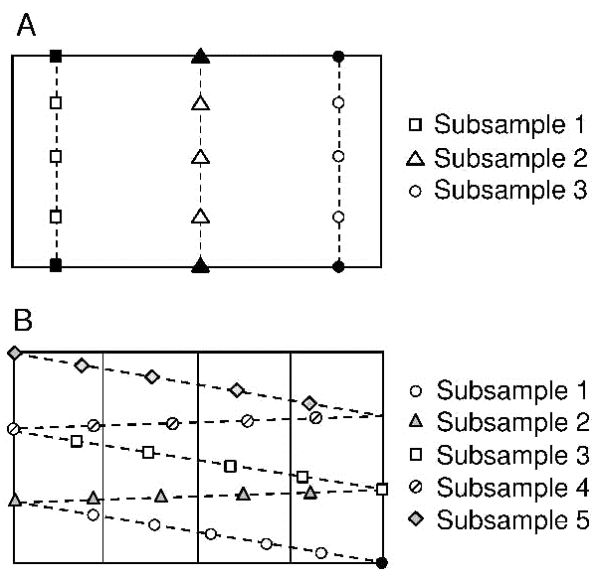

Fig. 1. Diagrams of soil cores taken from A, growers' parcels and $\mathbf{B}$, variety test plots. Five pooled soil cores from each of three subsamples were collected from each of the growers' parcels across the width of the parcel. Five pooled cores from each of five subsamples were collected diagonally across the length of each plot. Black shapes in A and in B indicate where global positioning system coordinates were acquired relative to the cores.
DNA extraction. The subsamples served as replicates for the parcel or plot in statistical analyses.

Soil extractions and real-time PCR. Total DNA was extracted from $0.5 \mathrm{~g}$ fresh weight of soil for each sample, as described by Okubara et al. (16). Briefly, soil was suspended in $300 \mu \mathrm{l}$ of bead solution, $60 \mu \mathrm{l}$ of buffer S1, and $120 \mu \mathrm{l}$ of Inhibitor Removal Solution (UltraClean Soil DNA Kit; MO BIO Laboratories, Solana Beach, CA) and subjected to 15 cycles of $35,000 \mathrm{psi}$ $(235 \mathrm{MPa})$ for $20 \mathrm{~s}$ alternated with $5 \mathrm{~s}$ of ambient pressure. Following the pressure cycling extraction, samples were processed according the UltraClean soil DNA kit protocol (16). Primers for real-time PCR are described by Okubara et al. (17). Standard curve equations for pathogen DNA quantification were cycle threshold $(\mathrm{Ct})=-3.805(\log$ pg DNA $)+28.388$ for $R$. solani AG8 and $\mathrm{Ct}=-3.857(\log$ pg DNA $)+29.814$ for $R$. oryzae genotype III. Pathogen concentration was calculated from the standard curves as picograms of DNA per gram of soil.

Meteorological and agroclimate data. The meteorological data consisted of precipitation (in millimeters), and maximum and minimum temperatures (in ${ }^{\circ} \mathrm{C}$ ) from 1979 to 2010 , scaled to $4 \mathrm{~km}$ (1). We extracted data from pixels co-located with site GPS coordinates. For correlations between pathogen concentrations and meteorological data, we used the following subsets of precipitation data: (i) cumulative precipitation (Pre; in millimeters) for October of the year prior to sampling through June of the sampling year (Oct-Jun), representing the wettest 9-month interval of the winter wheat growing season; (ii) cumulative precipitation for the 3 months prior to the sampling date (March to May [MarMay]); and (iii) cumulative precipitation for the three driest months in the year prior to sampling (July to September [JulSep]). For the Bickleton sites, data for April to June (Apr-Jun) was used instead of that for Mar-May, because these sites were sampled in mid-June. Average maximum (Max) and minimum (Min) temperatures were determined for the same Oct-Jun and Mar-May intervals. Additionally, we considered Jul-Sep, as used for precipitation, for the "warmest" maximum temperature interval, and November of the year prior to sampling through March of each sampling year (Nov-Mar) for the "coldest" minimum temperature interval.

Each sampling location was assigned a precipitation zone (PZ1 to 3) based on previous annual rainfall averages listed at the WSU Cereal and Grain Legume Variety Testing website (http://variety. wsu.edu/), where PZ1 = <305 mm (12 in.), $\mathrm{PZ2}=305$ to $508 \mathrm{~mm}$ (12 to 20 in.), and PZ3 $=>508 \mathrm{~mm}$ of annual precipitation. Agroclimate zones (ACZs) were determined from the GPS coordinates for each location using ArcMap 9.3 (ArcGIS Server 9.3; ESRI, Redlands, CA). The ACZs were defined by Douglas et al. (5) as $1=$ annual crop-wet-cold, $2=$ annual crop-wet-cool, $3=$ annual crop-fallow-transition, $4=$ annual crop-dry, $5=$ grainfallow, and $6=$ irrigated, and were adjusted to current cropping practices, in cases where they had shifted in the transition zones over the last 20 years.

Soil texture properties. The percentages of silt, clay, and sand were determined for all GPS coordinates using ArcMap 9.3 (ESRI) (21). The rating options were "weighted average" for Aggregation Method, "higher" for Tie-Break Rule, and top depth of $1 \mathrm{~cm}$ and bottom depth of $10 \mathrm{~cm}$ for Layer Options. These specifications generated soil texture values from data for the upper $10 \mathrm{~cm}$ of soil where available.

Tillage and rotation. Tillage practice and crop field history (rotation) data were collected from the grower cooperators in this study (Table 1). Tillage and cropping history were assigned numbers for subsequent analysis of their effects on pathogen DNA concentration using JMP (SAS Institute, Inc., Cary, NC), as described in the "Analysis of variance and pairwise correlation analyses" section. Parcels were categorized as 1 if they were direct-seeded at the time of sampling and 2 if they were tilled. Crop types were cereal (wheat or barley) $=1$, broadleaf (pea, 
chickpea, lentil, or canola) $=2$, and fallow $=3$. Information about the crop planted immediately prior to the sampled wheat in variety test plots was available through the WSU Cereal and Grain Legume Variety Testing website.

Pathogen data transformations. Values for pathogen DNA were converted from picograms per gram of soil to femtograms per gram +1 , to assign a positive value of 1.0 to samples in which no pathogen was detected. Transformed values, converted to $\log _{10}$ femtogram DNA, were used for all statistical analyses. Year-byyear comparisons were done on samples from 28 growers' parcels at nine locations and 20 variety test plots at 11 locations that were obtained in all three sampling years (2006 to 2008). Samples in which pathogen was not detected or quantified were excluded from correlation analyses and principal component analyses (PCAs), after frequency analysis showed that these zero samples were evenly distributed across all climate zones and comprised 40 to $60 \%$ of the samples in all locations. Data from growers' parcels and variety test plots were combined for $R$. solani AG8 and R. oryzae.

Analysis of variance and pairwise correlation analyses. One grower location in each of three cropping zones was selected for year-to-year comparisons of precipitation and temperature maxima and minima. Parcels $\mathrm{CH} 1$ to $\mathrm{CH} 3, \mathrm{HJ} 1$ to $\mathrm{HJ} 4$, and $\mathrm{DH} 1$ to $\mathrm{DH} 3$ represented PZ1, PZ2, and PZ3, respectively. Means and standard deviations were obtained for each sampling year, and means were separated into classes using Fisher's protected least significant difference at $P<0.05$ (Statistix version 8.1; Analytical Software, Tallahassee, FL).
Effects of tillage and previously planted or current crop type (cereal, broadleaf, or fallow) were tested for effects on logtransformed concentrations of $R$. solani AG8 or $R$. oryzae using the Fit Model algorithm of JMP 10.0.0 (SAS Institute, Inc.). The number of samples from direct-seeded and tilled parcels was balanced ( $n=58$ of each for 2006 to 2008). Significance of effects was examined using Student's $t$ test or Tukey's honestly significant difference models in JMP. Data from all three sampling years were combined for this analysis. Effect tests were also performed to determine whether pathogen DNA concentration varied by $\mathrm{PZ}$ or by year.

Pearson's algorithm of the PROC CORR Procedure (SAS version 9.2; SAS Institute, Inc.) was used to carry out pairwise correlation analyses between pathogen DNA concentrations and meteorological or soil texture data from the combined 2006 to 2008 data set, with grower fields and variety testing sites combined.

PCA. For PRINCOMP analysis, growers' parcels BS and PM (collected in 2007 and 2008), SM3-SM5 (collected in 2006, 2007, and 2008, respectively), and variety test plot samples from Bickleton (collected only in 2008) were omitted because they were not represented in all 3 years of the survey. Each set of pathogen DNA data was analyzed simultaneously with precipitation, temperature, and soil texture variables that were found to be significantly correlated in the PROC CORR analysis; variables with no significant correlation to the specific pathogen were omitted. Variables (factors) were co-analyzed using PRINCOMP (SAS Institute, Inc.). The number of principal components (Prins)

TABLE 1. Grower parcels sampled for this survey, and corresponding soil texture properties

\begin{tabular}{|c|c|c|c|c|c|c|c|c|}
\hline \multirow[b]{2}{*}{ Parcel $^{\mathrm{a}}$} & \multirow[b]{2}{*}{ Location $^{\mathrm{b}}$} & \multirow[b]{2}{*}{ Tillage } & \multirow[b]{2}{*}{ Rotation $^{\mathrm{c}}$} & \multirow[b]{2}{*}{$P Z^{\mathrm{d}}$} & \multirow[b]{2}{*}{$\mathrm{ACZ}$} & \multicolumn{3}{|c|}{ Soil texture properties $(\%)^{\mathrm{e}}$} \\
\hline & & & & & & Silt & Clay & Sand \\
\hline DH1 & Pullman, Whitman & Tilled & Chickpea-WW-SW & 3 & 2 & 67.7 & 21.0 & 11.3 \\
\hline $\mathrm{DH} 2$ & & & SW-SW-chickpea & 3 & 2 & 67.7 & 21.0 & 11.3 \\
\hline DH3 & & & WW-SW-chickpea & 3 & 2 & 67.7 & 21.0 & 11.3 \\
\hline BN1 & Farmington, Whitman & Direct seeded & SW-pea-WW & 3 & 2 & 71.0 & 15.0 & 14.0 \\
\hline $\mathrm{BN} 2$ & & & Pea-WW-SW & 3 & 2 & 71.0 & 15.0 & 14.0 \\
\hline $\mathrm{BN} 3$ & & & WW-SW-lentil & 3 & 2 & 67.7 & 21.0 & 11.3 \\
\hline RP1 & Garfield, Whitman & Direct seeded & WW-WW-WW & 3 & 2 & 67.7 & 21.0 & 11.3 \\
\hline RP2 & & & WW-WW-WW & 3 & 2 & 68.0 & 22.5 & 9.5 \\
\hline RP3 & & & SW-SW-WW & 3 & 2 & 52.0 & 21.0 & 24.5 \\
\hline RP4 & & & WW-WW-SW & 3 & 2 & 68.0 & 10.3 & 9.5 \\
\hline BS1 & Spangle, Spokane & Direct seeded & ns-SW-lentil & 2 & 4 & 69.5 & 19.9 & 10.6 \\
\hline BS2 & & & ns-lentil-WW & 2 & 4 & 69.5 & 19.9 & 10.6 \\
\hline HJ1 & Davenport, Lincoln & Tilled & WW-SW-fallow & 2 & 4 & 73.2 & 12.5 & 14.3 \\
\hline $\mathrm{HJ} 2$ & & & Barley-WW-SW & 2 & 4 & 73.2 & 12.5 & 14.3 \\
\hline HJ3 & & & SW-SW-SW & 2 & 4 & 73.2 & 12.5 & 14.3 \\
\hline HJ4 & & & Canola-SW-WW & 2 & 4 & 73.2 & 14.0 & 14.3 \\
\hline JA1 & Almota, Whitman & Direct seeded & SW-SW-WW & 2 & 3 & 67.7 & 21.0 & 11.3 \\
\hline JA2 & & & WW-SW-WW & 2 & 3 & 67.7 & 21.0 & 13.6 \\
\hline PM1 & Spangle, Spokane & Direct seeded & (SW)-lentil-WW & 2 & 4 & 65.4 & 14.5 & 20.1 \\
\hline PM2 & & & (SW)-lentil-WW & 2 & 4 & 65.4 & 14.5 & 20.1 \\
\hline RS1 & Steptoe, Whitman & Tilled & WW-SW-pea & 2 & 2 & 67.7 & 21.0 & 11.3 \\
\hline RS2 & & & SW-pea-WW & 2 & 2 & 67.7 & 21.0 & 11.3 \\
\hline RS3 & & & Pea-WW-SW & 2 & 2 & 67.7 & 21.0 & 11.3 \\
\hline $\mathrm{CH} 1$ & Ralston, Adams & Tilled & WW-tilled fallow-WW & 1 & 5 & 70.8 & 7.5 & 21.7 \\
\hline $\mathrm{CH} 2$ & & & SW-tilled fallow-WW & 1 & 5 & 70.8 & 7.5 & 21.7 \\
\hline $\mathrm{CH} 3$ & & & Canola-SW-WW & 1 & 4 & 70.8 & 7.5 & 21.7 \\
\hline RJ1 & Ritzville, Adams & Direct seeded & SW-SW-SW & 1 & 5 & 70.8 & 7.5 & 21.7 \\
\hline $\mathrm{RJ} 2$ & & & Fallow-WW-fallow & 1 & 5 & 70.8 & 7.5 & 21.7 \\
\hline RJ3 & & & WW-fallow-WW & 1 & 5 & 70.8 & 7.5 & 21.7 \\
\hline SM1 & Bickleton, Klickitat & Direct seeded & SW-SW-SW & 1 & 4 & 71.8 & 14.0 & 14.2 \\
\hline $\mathrm{SM} 2$ & & & WW-SW-SW & 1 & 4 & 71.8 & 14.0 & 14.2 \\
\hline
\end{tabular}

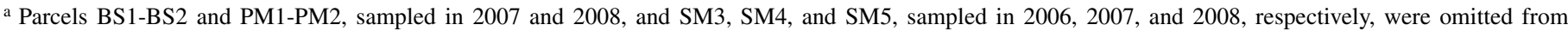
ANOVA because they occurred at different Global Positioning System locations.

b Nearest town, county.

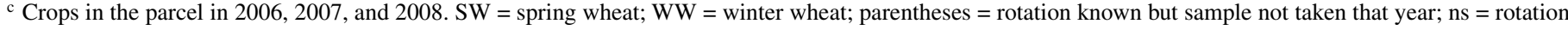
unknown, sample not taken.

${ }^{\mathrm{d}}$ Precipitation zone, where $1=<305 \mathrm{~mm}$ (12 in.), $2=305$ to $508 \mathrm{~mm}$ (12 to $20 \mathrm{in}$.), and $3=>508 \mathrm{~mm}$ ( $20 \mathrm{in}$.) of annual precipitation.

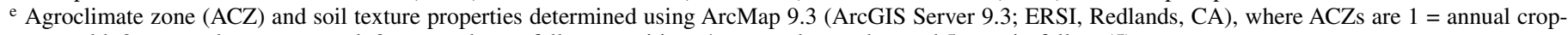
wet-cold; 2 = annual crop-wet-cool; 3 = annual crop-fallow-transition; $4=$ annual crop-dry; and $5=$ grain-fallow (5). 
used in the analyses was determined by the number of eigenvalues of the correlation matrix $>1.0$. Component Pattern plots were generated to observe the relative variation within each variable and to plot clustering of variables. Component Score plots were used to visualize the sampling sites relative to the two major components of variation, Prin1 and Prin2, to determine which groups of factors explained the separation of sampling sites.

A second analysis was done using JMP 10.0 Principal Component (SAS Institute, Inc.); pathogen DNA concentration data; and all precipitation, temperature, and soil texture variables, regardless of whether they were significantly correlated in the PROC CORR analysis. Data from growers' parcels and variety test plots for 2006 to 2008 were combined but Bickleton samples were omitted. Biplots showing the vector length and directions of the variables were constructed using the Multivariate Methods program, and significant $(P<0.05)$ correlations among factors were determined using the Multivariate and Pairwise Correlations algorithms of JMP 10.0.

\section{RESULTS}

Our parcel/plot sampling scheme, shown in Figure 1, was intended to account for the patch-like occurrence of Rhizoctonia spp. in the field (28). In total, 582 soil samples were collected in 2006 to 2008. These included growers' parcels (Table 1) and variety test plots (Table 2). However, a subset of 495 samples that carried $R$. solani AG8 or $R$. oryzae and were from locations common to all 3 years were used for analyses. Analysis of variance (ANOVA) showed no significant differences in pathogen DNA concentration among the sample reps or subsamples (transects) within each parcel. However, 40 to $60 \%$ of the samples were zero values (no DNA detected). The frequency of zero values for $R$. solani AG8 at all sites, plotted relative to total precipitation for the Mar-May interval, is shown in Supplemental Figure 1. Rainfall varied from year to year; therefore, the data in each bar did not always represent a single PZ; however, the expected trend is that bars at the left portion of the graph mainly comprised samples from PZ1. Despite the expectation that $R$. solani AG8 should occur more often in low-PZs, the zero samples were evenly distributed across all zones. This was attributed to the equal occurrence and distribution of spots or patches of the pathogens in all zones (28). Analysis of correlations and PCAs were carried out using only the data where the pathogen was detected or quantified. Growers' parcels were monotonic with respect to cultivar and GPS location and were sampled less intensively than variety test plots. However, spatial variability in pathogen DNA concentration was similar for the sampling scales at both types of sites, and parcels or plots did not give significant effects in ANOVA.

Yearly variation in meteorological and pathogen data. The growers' parcels and variety test plots used in this study were representative of dryland wheat production systems in the state of Washington. The sites generally sustained more precipitation and

TABLE 2. Washington State University cereal variety testing sites and corresponding soil properties used in this survey

\begin{tabular}{|c|c|c|c|c|c|c|c|}
\hline \multirow[b]{2}{*}{ Test plot ${ }^{\mathrm{a}}$} & \multirow[b]{2}{*}{ County } & \multirow[b]{2}{*}{ Years sampled } & \multirow[b]{2}{*}{$\mathrm{PZ}^{\mathrm{b}}$} & \multirow[b]{2}{*}{$\mathrm{ACZ}$} & \multicolumn{3}{|c|}{ Soil texture properties $(\%)^{\mathrm{c}}$} \\
\hline & & & & & Silt & Clay & Sand \\
\hline Bickleton SW & Klickitat & 2008 & 1 & 4 & 71.8 & 14.0 & 14.2 \\
\hline Bickleton WW & & 2008 & 1 & 4 & 68.8 & 10.0 & 21.1 \\
\hline Connell SW & Franklin & $2006,2007,2008$ & 1 & 5 & 70.8 & 7.5 & 21.7 \\
\hline Connell WW & & $2006,2007,2008$ & 1 & 5 & 70.8 & 7.5 & 21.7 \\
\hline Harrington WW1 & Lincoln & 2006,2008 & 1 & 5 & 70.8 & 7.6 & 21.7 \\
\hline Harrington WW2 & & 2007 & 1 & 5 & 69.9 & 8.5 & 14.6 \\
\hline Lind SW & Adams & $2006,2007,2008$ & 1 & 5 & 70.8 & 7.5 & 21.7 \\
\hline Lind WW1 & & 2006,2008 & 1 & 5 & 70.8 & 7.5 & 21.7 \\
\hline Lind WW2 & & 2007 & 1 & 5 & 70.8 & 7.5 & 21.7 \\
\hline Ritzville SW & Adams & 2006, 2007 & 1 & 5 & 70.8 & 7.5 & 21.7 \\
\hline Ritzville WW & & $2006,2007,2008$ & 1 & 5 & 70.8 & 7.5 & 21.7 \\
\hline Dayton SW1 & Columbia & 2006 & 2 & 2 & 68.9 & 17.5 & 13.6 \\
\hline Dayton SW2 & & 2007 & 2 & 2 & 67.7 & 21.0 & 11.3 \\
\hline Dayton SW3 & & 2008 & 2 & 2 & 68.9 & 17.5 & 13.6 \\
\hline Dayton WW & & $2006,2007,2008$ & 2 & 2 & 68.9 & 17.5 & 13.6 \\
\hline Dusty SW1 & Whitman & 2006 & 2 & 3 & 73.2 & 12.5 & 14.3 \\
\hline Dusty SW2 & & 2008 & 2 & 3 & 68.9 & 17.5 & 13.6 \\
\hline Dusty WW1 & & 2006 & 2 & 3 & 73.2 & 12.5 & 14.3 \\
\hline Dusty WW2 & & 2007, 2008 & 2 & 3 & 57.4 & 9.5 & 33.1 \\
\hline St. John SW & Whitman & $2006,2007,2008$ & 2 & 3 & 68.9 & 17.5 & 13.6 \\
\hline St. John WW & & $2006,2007,2008$ & 2 & 3 & 68.9 & 17.5 & 13.6 \\
\hline Walla Walla SW1 & Walla Walla & 2006,2008 & 2 & 3 & 73.2 & 12.5 & 14.3 \\
\hline Walla Walla SW2 & & 2007 & 2 & 3 & 71.8 & 14.0 & 14.2 \\
\hline Walla Walla WW1 & & 2006, 2007 & 2 & 3 & 73.2 & 12.5 & 14.3 \\
\hline Walla Walla WW2 & & 2008 & 2 & 2 & 71.8 & 14.0 & 14.2 \\
\hline Colton WW1 & Whitman & 2006 & 3 & 2 & 71.0 & 15.0 & 14.0 \\
\hline Colton WW2 & & 2007 & 3 & 2 & 68.6 & 23.5 & 11.4 \\
\hline Colton WW3 & & 2008 & 3 & 2 & 52.0 & 23.5 & 24.5 \\
\hline Farmington SW & Whitman & $2006,2007,2008$ & 3 & 2 & 71.0 & 15.0 & 14.0 \\
\hline Farmington WW1 & & 2006 & 3 & 2 & 71.0 & 15.0 & 14.0 \\
\hline Farmington WW2 & & 2007 & 3 & 2 & 54.0 & 23.5 & 19.0 \\
\hline Farmington WW3 & & 2008 & 3 & 2 & 54.0 & 27.0 & 19.0 \\
\hline Pullman SW & Whitman & $2006,2007,2008$ & 3 & 2 & 67.7 & 21.0 & 11.3 \\
\hline Pullman WW1 & & 2006 & 3 & 2 & 54.0 & 27.0 & 19.0 \\
\hline Pullman WW2 & & 2007 & 3 & 2 & 54.0 & 27.0 & 19.0 \\
\hline Pullman WW3 & & 2008 & 3 & 2 & 69.3 & 18.2 & 12.6 \\
\hline
\end{tabular}

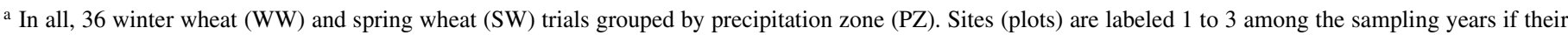
Global Positioning System coordinates resulted in differences in one or more variables. In total, 60 samples were collected at the 36 sites from 2006 to 2008.

${ }^{\mathrm{b}} \mathrm{PZ1}=<305 \mathrm{~mm}$ (12 in.), PZ2 = 305 to $508 \mathrm{~mm}$ (12 to $20 \mathrm{in}$.), and PZ3 = >508 $\mathrm{mm}$ (20 in.) of annual precipitation.

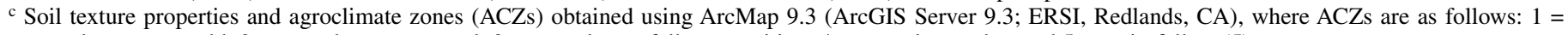
annual crop-wet-cold; 2 = annual crop-wet-cool; 3 = annual crop-fallow-transition; 4 = annual crop-dry; and 5 = grain-fallow (5). 
slightly higher minimum temperatures in 2006 compared with 2007 and 2008, as represented by selected grower sites (Supplemental Table 1). Maximum temperatures were slightly higher in PZ1 and PZ2 in 2007. $R$. solani AG8 and $R$. oryzae genotype III were present in growers' parcels in all three sampling years (Table 3). JMP-based effect tests indicated that both pathogen DNA concentrations significantly $(P<0.05)$ differed by year but only that of $R$. solani AG8 was affected by PZ (data not shown). It is important to note that DNA values for each pathogen result from a pathogen-specific standard curve and are not directly comparable across pathogen species.

Pathogen DNA concentrations are correlated to meteorological and soil texture properties in a pathogen-specific manner. Correlation coefficients and $P$ values $(<0.05$ only) for pathogen DNA concentrations in growers' parcels and variety test plots, plus meteorological or soil texture variables, are shown in Table 4. $R$. solani AG8 DNA concentration was negatively correlated $(P<0.05)$ with cumulative rainfall for the 3 months prior to sample collection (Mar-May), to the "wettest" interval (OctJun) prior to and during pathogen sampling, and to the "driest" 3-month interval prior to sample collection (Jul-Sep) (Table 4; Fig. 2). Significant correlations also were observed between $R$. solani AG8 and percent clay (negative) or percent sand (positive). Average monthly maximum temperatures for the Mar-May and Jul-Sep intervals and percent sand were significantly $(P<0.05)$ and positively correlated with $R$. solani AG8 (Table 4). These findings indicate that $R$. solani AG8 is more abundant in areas with lower precipitation, higher sand or lower clay content, and higher average air temperatures. Concentrations of $R$. oryzae DNA were similarly associated with average maximum temperature for the Mar-May interval and clay and sand content. However, $R$. oryzae was also positively correlated to average monthly temperature maxima for the Oct-Jun interval but not the Jul-Sep interval, and to average monthly temperature minima for all three intervals. This pathogen was not correlated to precipitation (Table 4 ). The data suggest that $R$. oryzae occurs across all PZs, in areas having sandy rather than clay soil and cooler average air temperatures in the summer months relative to $R$. solani AG8.

Effects of tillage and rotation on Rhizoctonia DNA concentrations. To test the hypotheses that Rhizoctonia spp. accumulated more in direct-seeded than in tilled fields, we analyzed the effect of tillage practice on pathogen concentrations in growers' parcels across three Washington PZs and four ACZs for the combined three sampling years. $R$. solani AG8 was higher in direct-seeded plots at $P=0.06$, with a significant interaction with year $(P=0.002)$. The values (direct-seed/tilled) were $2.79 / 2.44$, $3.16 / 2.76$, and 3.22/3.11 log fg DNA in 2006, 2007, and 2008, respectively. However, there was no effect of tillage on $R$. oryzae $(P=0.22)$.

Data from the growers' parcels and variety test plots were combined for analysis of the effect of the previously planted crop on $R$. solani AG8 and $R$. oryzae. The effect of previous crop on $R$. solani AG8 was found to be significant $(P=0.0234)$ and was attributed to a reduction in pathogen concentration when the previously planted crop was a broadleaf, usually a legume such as pea. There was no interaction between previous crop and year

TABLE 3. Pathogen concentrations found at growers' parcels and variety test plots averaged over the 3-year survey period ${ }^{\mathrm{a}}$

\begin{tabular}{|c|c|c|c|c|c|c|}
\hline \multirow[b]{2}{*}{ Species } & \multicolumn{3}{|c|}{ Growers' parcels } & \multicolumn{3}{|c|}{ Variety test plots } \\
\hline & $\mathrm{PZ}$ & fg DNA $^{b}$ & Prevalence & PZ & fg DNA ${ }^{c}$ & Prevalence \\
\hline \multirow[t]{3}{*}{ Rhizoctonia solani AG8 } & 1 & $5,000 \pm 1,865$ & 0.917 & 1 & $1,096 \pm 372$ & 1.000 \\
\hline & 2 & $1,520 \pm 980$ & 0.733 & 2 & $820 \pm 212$ & 0.909 \\
\hline & 3 & $261 \pm 78$ & 0.633 & 3 & $164 \pm 42$ & 0.867 \\
\hline \multirow[t]{3}{*}{ R. oryzae } & 1 & $1,990 \pm 688$ & 0.583 & 1 & $1,117 \pm 731$ & 0.600 \\
\hline & 2 & $1,470 \pm 875$ & 0.667 & 2 & $561 \pm 218$ & 0.500 \\
\hline & 3 & $597 \pm 301$ & 0.433 & 3 & $594 \pm 322$ & 0.600 \\
\hline
\end{tabular}

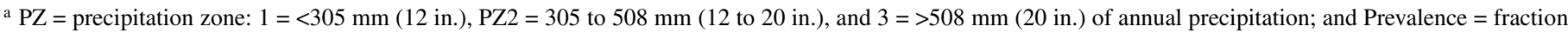
of parcels or plots in which the pathogen was detected or quantified.

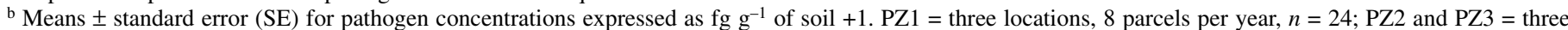
locations, 10 parcels per year, $n=30$.

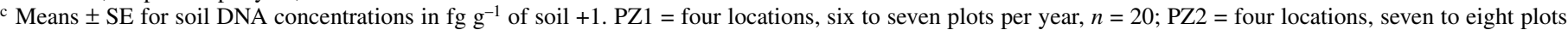
per year, $n=22$; and PZ3 = three locations, five plots per year, $n=15$.

TABLE 4. Correlation coefficients and probabilities (in parentheses) between pathogen concentrations in log fg DNA and global positioning system-based precipitation, temperature, or soil texture properties in growers' parcels and variety test plots $^{\mathrm{a}}$

\begin{tabular}{|c|c|c|}
\hline Properties & Rhizoctonia solani AG8 & R. oryzae \\
\hline \multicolumn{3}{|l|}{ Cumulative precipitation $^{\mathrm{b}}$} \\
\hline March-May & $-0.29951(<0.0001)$ & ns \\
\hline October-June & $-0.32585(<0.0001)$ & ns \\
\hline \multicolumn{3}{|l|}{ Maximum temperature ${ }^{\mathrm{c}}$} \\
\hline Average March-May & $0.19185(0.0011)$ & $0.24408(0.0016)$ \\
\hline Average October-June & $\mathrm{ns}$ & $0.22204(0.0042)$ \\
\hline Average July-September & $0.25238(<0.0001)$ & $\mathrm{ns}$ \\
\hline Average October-June & $\mathrm{ns}$ & $0.25156(0.0011)$ \\
\hline Average November-March & $\mathrm{ns}$ & $0.23971(0.0019)$ \\
\hline \multicolumn{3}{|l|}{ Soil properties ${ }^{\mathrm{d}}$} \\
\hline Percent clay & $-0.23769(<0.0001)$ & $-0.31077(<0.0001)$ \\
\hline Percent sand & $0.25224(<0.0001)$ & $0.19873(0.0105)$ \\
\hline Percent silt & ns & $\mathrm{ns}$ \\
\hline
\end{tabular}

${ }^{a}$ Probabilities (in parentheses) if $P \leq 0.05 ;$ ns $=$ not significant $(P>0.05)$.

${ }^{\mathrm{b}}$ Cumulative precipitation $(\mathrm{mm})$ for the specified intervals relevant to each sampling year.

${ }^{\mathrm{c}}$ Monthly average maximum or minimum temperatures for the specified intervals relevant to each sampling year.

d Obtained using ArcMap 9.3 (ArcGIS Server 9.3; ESRI, Redlands, CA). 
$(P=0.7587)$; thus, the average value for $R$. solani was $2.9 \log \mathrm{fg}$ DNA when the previous crop was a cereal, 2.5 when the previous crop was a broadleaf, and 2.8 when in fallow the previous year. No effect of previously planted crop on $R$. oryzae soil concentrations was observed.

Rhizoctonia pathogens are associated with different groups of meteorological and soil variables in PCA. The Rhizoctonia spp. were analyzed individually, because pairwise correlation analyses indicated that each was affected by different variables. A separate PCA was done for $R$. solani AG8 data from each year to reduce the complexity of the PCA output. For all but one of the analyses, 75 to $80 \%$ of the variance in the data was explained by two Prins; three components explained the variance for the $R$. solani AG8 year 3 (2008) data set.

Component scores plots were generated to visualize each sample relative to the major PCA components. Except for the example described below, the factors within each component had nearly equal loadings (weights). An example of a plot of each sample relative to components 1 and 2 for year 1 of the $R$. solani AG8 data set is shown in Figure 3. In this case, component 1 comprised the factors PreOct-Jun, MaxMar-May, soil pH, percent clay, and percent sand, and component 2 comprised PreMar-May, PreJul-Sep, and MaxJul-Sep. The PreJul-Sep factor was the dominant factor in component 2. The low-precipitation, high-sand samples, such as Connell and Lind variety test plot samples, fell at the right of the plot along component 1 , whereas the highprecipitation, high-clay samples were at the left. Component 2 distinguished high PreMar-May/low PreJul-Sep samples (at the top of the plot) from those having low PreMar-May/high PreJulSep (bottom of plot). Samples harboring quantifiable levels $(\geq \log$ fg DNA $=2.5$ ) of $R$. solani AG8 are shown in large- and mediumsized dots in Figure 3 and color-coded in Supplemental Table 2.
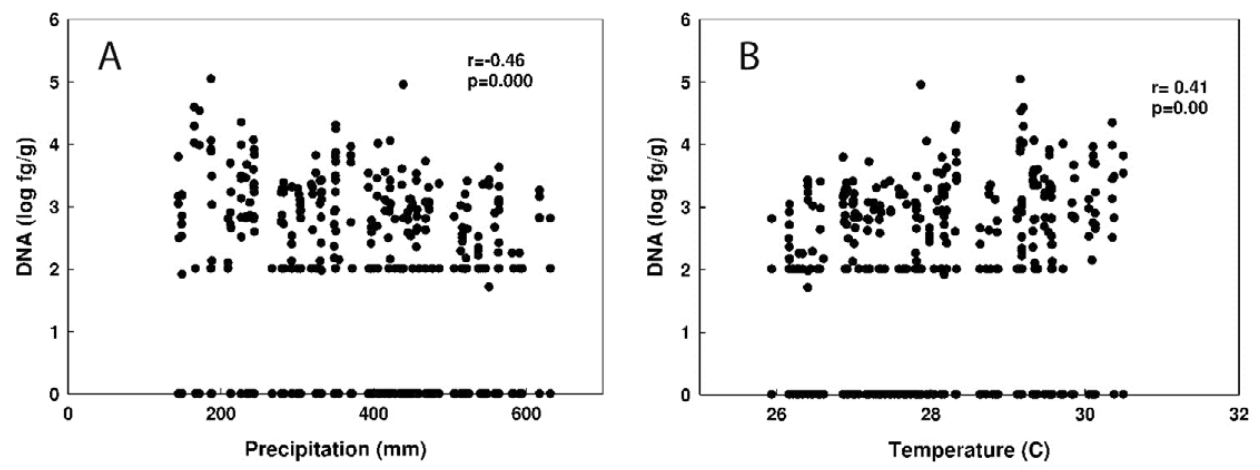

Fig. 2. Relationship between A, Rhizoctonia solani AG8 concentration (log fg DNA/g of soil) and cumulative precipitation (mm) for the October to June interval or $\mathbf{B}$, average monthly temperature maxima $\left({ }^{\circ} \mathrm{C}\right)$ for the July to October interval. Data from growers' parcels and variety test plots for 3 years were pooled; $r=$ Pearson's correlation coefficient. Zero values were excluded from the analysis.

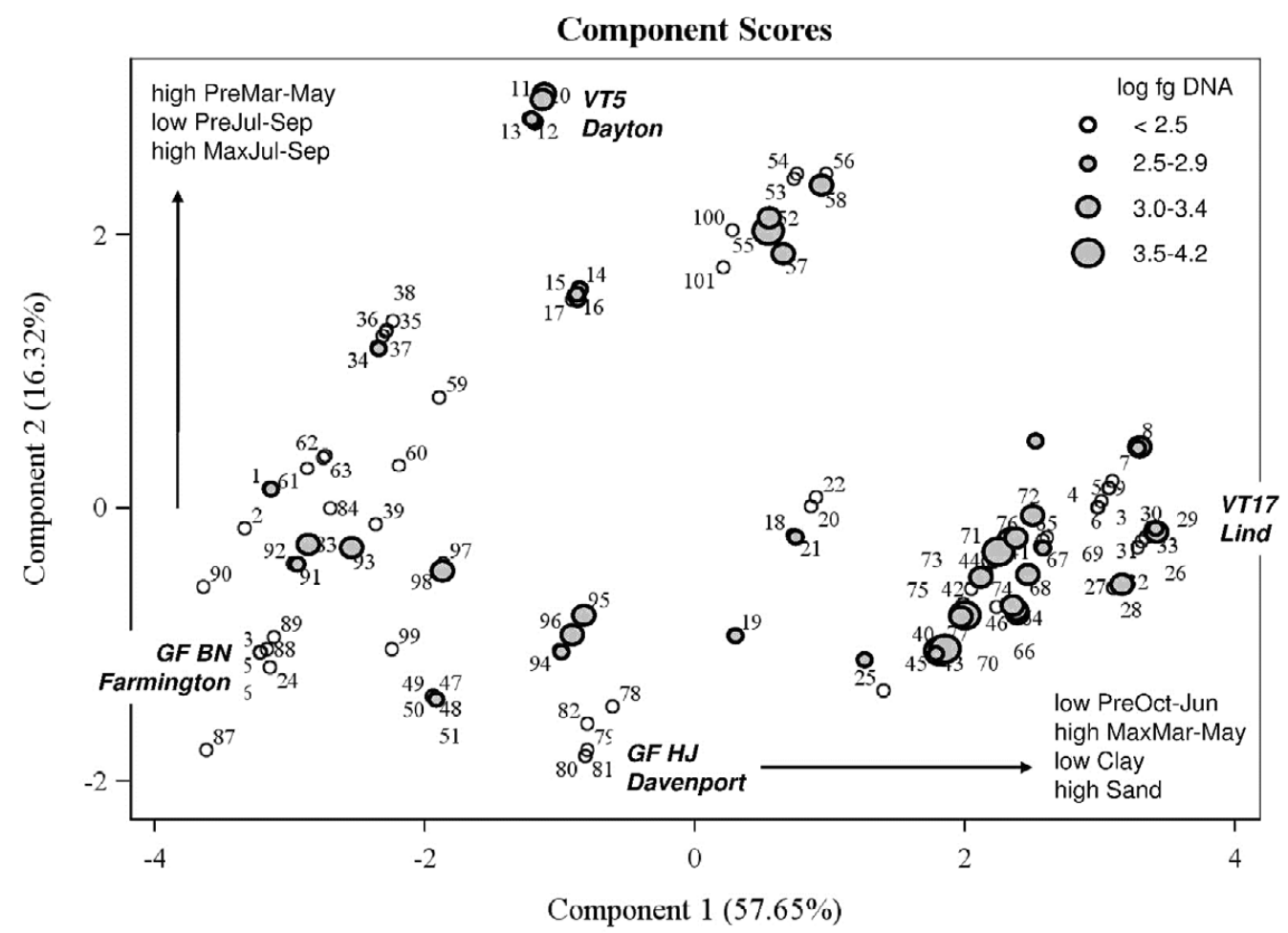

Fig. 3. Component scores plots (PRINCOMP, SAS Institute, Inc.) for the Rhizoctonia solani AG8 data set from growers' parcels and variety test plots for 2006 (year 1), showing the distribution of sampling sites by cumulative precipitation (Pre) in the October to June (Oct-Jun) interval, average monthly temperature maxima in the March to May (Mar-May) interval, percent clay, and percent sand (component 1), plotted against cumulative precipitation in the Mar-May and July-September (Jul-Sep) intervals, and average monthly temperature maxima in the Jul-Sep interval (component 2). Gray dots indicate samples harboring quantifiable levels ( $\geq 2.5 \log$ fg DNA) of the pathogen, where the size of the dot is proportional to pathogen DNA concentration; open dots indicate samples in which pathogen was detectable but not quantifiable $(<2.5 \log$ fg DNA). A key to the sample numbers is given in Supplemental Table 2. 
The trends in component factors seen for $R$. solani AG8 in year 1 also were observed in year 2 . In year 3 , however, component 2 separated the samples according to PreJul-Sep only, the PreMarMay factor was associated with component 1, and MaxMar-May and MaxJul-Sep factors were captured in a third component.

The distribution of the $R$. oryzae samples in years 1 and 2 was explained by high MaxOct-Jun, high MinMar-May, high MinOctJun, and high MinNov-Mar (component 1) and high MaxMarMay, low clay, and high sand (component 2). Because the distributions were very similar, data from both years were combined. Year 3 data for $R$. oryzae were omitted because they comprised a relatively small number of samples $(n=21)$, all having detectable but not quantifiable $(<2.5 \log$ fg DNA) pathogen levels. In summary, $R$. solani AG8 accumulated in low to intermediate PZs, in areas having higher temperature maxima and sandy soils, whereas $R$. oryzae persisted in areas having low temperature minima.

JMP Principal Component analysis, conducted using all variables for 2006 to 2008, resulted in a biplot of the vectors of the independent and dependent variables for $R$. solani and $R$. oryzae (Fig. 4). Longer vectors indicated factors that had major contributions to variation in the dataset, whereas shorter vectors indicated factors that were relatively minor. Vectors having the same directionality are positively correlated to each other, whereas those in opposing directions are negatively correlated. The JMP Principal Component analysis generally identified the same sets of variables associated with $R$. solani AG8 or $R$. oryzae DNA concentration as did PRINCOMP (Fig. 4A). The vector for $R$. solani AG8 (logAG8) was directionally the same as that for sand but opposite the precipitation and clay vectors, indicating that DNA concentrations of this pathogen are higher in sandy soils and lower in soils from high-clay and high-precipitation regions. The concentration of AG8 DNA was more closely aligned with maximum than minimum temperature. Overall, the first two components explained $61 \%$ of the variation. The short $R$. oryzae (log Ro) vector indicated that it is not a major factor in explaining the variation within the dataset, and was neither positively nor negatively correlated to precipitation and soil properties (Fig. 4B). However, the log Ro vector was weakly correlated, if at all, to temperature maxima and minima in JMP Principal Component analysis compared with PRINCOMP. Components 1 and 2 explained $\approx 69 \%$ of the variation.

\section{DISCUSSION}

Our survey has identified meteorological, soil texture, and cropping factors correlated to the abundance of $R$. solani AG8 and $R$. oryzae in soils of Washington state. This is the first report, to our knowledge, of the quantitative distribution of Rhizoctonia spp. across a large geographical area on a common host, and the relationship of distribution to climatic and soil factors. This biogeographical study only could have been possible in the last decade, because of two technological developments: (i) sensitive molecular techniques to quantify specific microorganisms from soil and (ii) the development geographic information systems, low-cost GPSs, and higher-resolution climate data at the $4-\mathrm{m}^{2}$ area scale. The former development is especially important for Rhizoctonia spp. because it occurs at low soil population densities that cannot be accurately quantified with traditional dilution plating techniques.

The relationship of climate and weather factors to disease distribution of foliar pathogens, such as rusts, is well understood. Models have been developed to relate weather factors to the distribution of stripe rust of wheat (35), soybean rust (20), and Septoria tritici on wheat (29) using the defined influences of temperature, precipitation, and relative humidity on the infection process and disease progression. Fewer studies have been conducted on the distribution of soilborne pathogens as affected by climate. Poole et al. (30) demonstrated that the two causal agents of Fusarium crown rot of wheat are differentially distributed in the PNW; Fusarium pseudograminearum O'Donnell \& T. Aoki was more dominant in areas with higher temperature, lower elevation, and lower precipitation whereas F. culmorum (W. G. Sm.) Sacc. was associated with higher precipitation areas and higher elevations. In a similar study, population densities of root lesion nematodes (Pratylenchus neglectus and P. thornei) were
A R. solani AG8

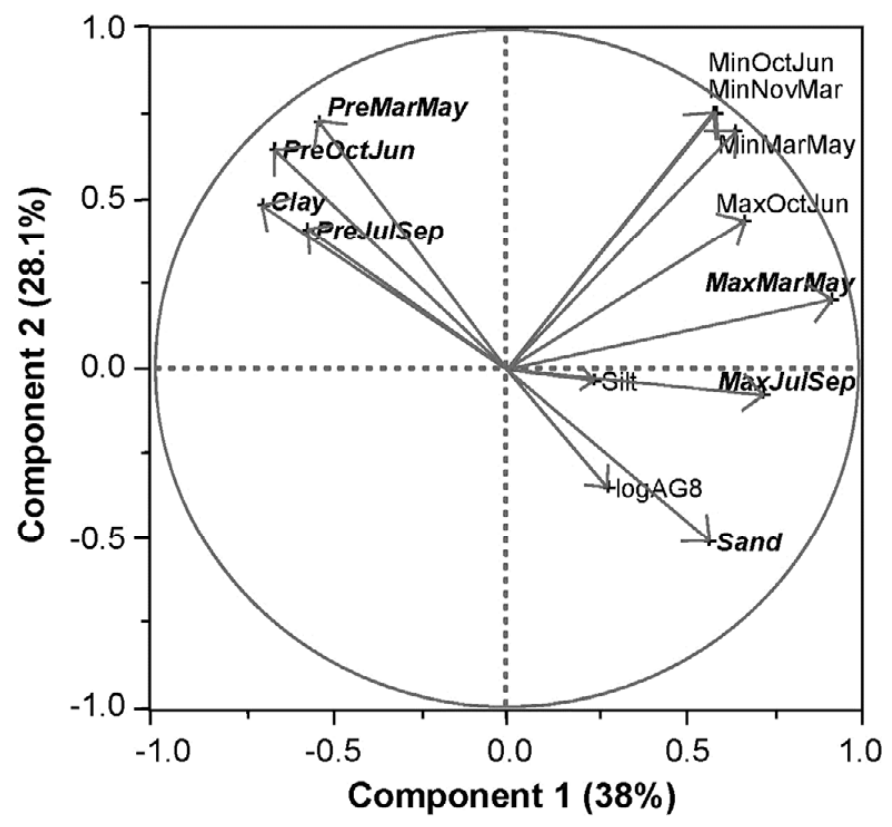

B R. oryzae

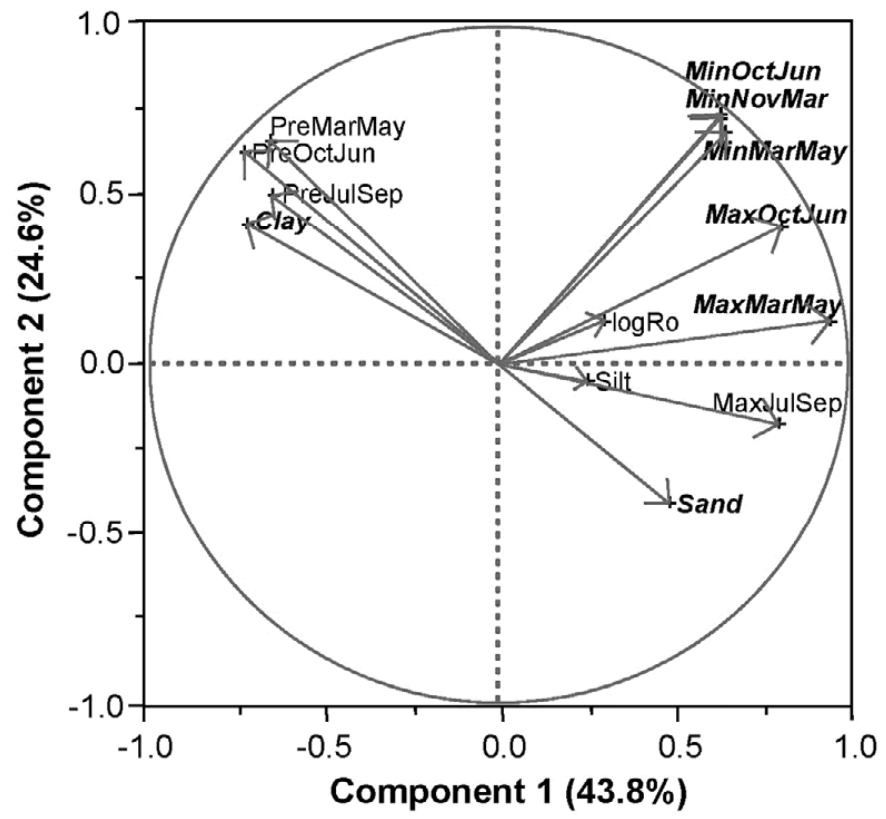

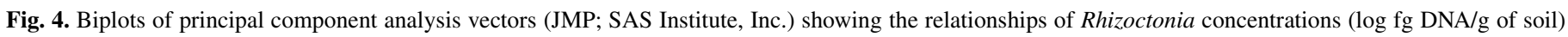

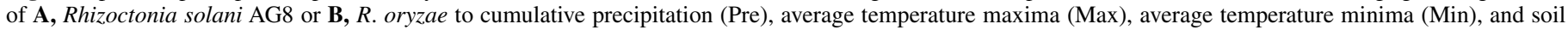

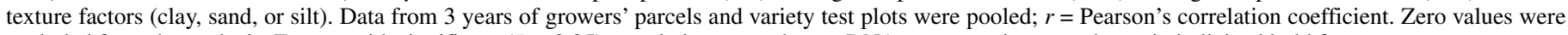
excluded from the analysis. Factors with significant $(P<0.05)$ correlations to pathogen DNA concentrations are shown in italicized bold font. 
more abundant in areas of high precipitation and continuous cropping, as opposed to drier areas where wheat was only grown every 2 years $(10)$.

We found that $R$. solani AG8 was distributed across the entire dryland cropping region but higher soil DNA concentrations were associated with lower precipitation, higher average atmospheric temperatures, and higher soil sand content. Soil temperature data were not available for the sites but would be highly correlated to atmospheric temperatures. Rhizoctonia bare patch symptoms are mostly observed in areas having these meteorological and soil conditions, a crescent from Ritzville to Connell, at the edge of the dryland cropping zone. Further west of this crescent, the annual precipitation is too low for growing wheat without irrigation. Bare patches also are observed south of Dayton and Walla Walla, which harbored relatively high soil pathogen DNA concentrations. Although $R$. solani is associated with bare patches in warm, dry regions, it also is manifest as general root rot and uneven stands in the higher-rainfall areas. It is clear that environment might affect not only the accumulation of inoculum in the soil but also the expression of the disease.

One unresolved question is why bare patch symptoms associated with acute infections do not develop in the higher-rainfall areas. Work of Australian researchers showed that sand was associated with higher disease levels. Gill et al. (6) found more root loss from $R$. solani AG8 in sandy soils compared with sandy loams or sandy clay loams. The clay soils of the high-rainfall areas of the PNW, having less sand, might be less conducive to the movement of the hyphae through the soil. Otten and colleagues $(18,19)$ showed that hyphae of $R$. solani AG4 prefer larger soil pores for faster spread and colonization. In the field, $R$. solani AG8 survives primarily as thick-walled hyphae in root matter; hence, host infection gives rise to more inoculum. Observations of higher soil pathogen DNA concentrations in sandy areas support the likelihood of a causal link between higher inoculum deposition, greater degree of root infection, and higher disease levels.

The relationship between Rhizoctonia root rot, temperature, and moisture was reported by Gill et al. (7), who demonstrated that, in moist soil, the disease was more severe at lower temperatures $\left(10^{\circ} \mathrm{C}\right)$. This observation confirmed the findings of Ogoshi et al. (15), who reported higher levels of disease at 10 compared with $20^{\circ} \mathrm{C}$. Because optimum temperature in culture was $25^{\circ} \mathrm{C}$, factors governing pathogen growth and disease under field conditions are distinct from those of the laboratory and even in pasteurized soils (P. Okubara, unpublished data). One explanation is that, under wetter, cooler conditions, soil microbes that normally suppress Rhizoctonia spp. are less active (8). For instance, decline of Rhizoctonia bare patches due to diseasesuppressive rhizobacteria has been observed at a site near Ritzville, WA $(13,38)$, under drier, warmer conditions.

In contrast to $R$. solani AG8, $R$. oryzae (W. circinata var. circinata) was more uniformly distributed throughout the dryland cropping regions of the state. Fewer studies have been done with $R$. oryzae, which can cause preemergence damping off of wheat and barley at cool temperatures $\left(12^{\circ} \mathrm{C}\right)(14,34)$. Our study indicated that $R$. oryzae DNA concentrations were not affected by precipitation but were significantly $(P<0.05)$ and consistently correlated with temperature minima. This pathogen also attacks broadleaf crops such as pea (22) and forms microsclerotia in plant tissue. Its persistence in cropping soils might be attributed to a broad host range as well as to longevity as microsclerotia, making it refractory to precipitation. Because $R$. oryzae is often found with $R$. solani AG8 in bare patches and direct-seeded fields (27), we hypothesized that these two pathogens would be governed by similar environmental factors, and might be co-managed as a complex. However, our data indicate that each pathogen was associated with a unique set of variables, such that they should not be managed as a complex.
Cropping history and tillage also were addressed to a limited degree in our survey. Rotations practiced by growers are optimized for soil and precipitation factors and the economics of inputs and production. The finding that $R$. solani AG8 soil concentration was reduced if a broadleaf crop was planted immediately before wheat supported observations that cropping history has a role in disease manifestation. It also suggests that rotation might reduce $R$. solani AG8, despite its pathogenicity to legumes and brassicas. However, whether these reductions in population are significant enough to result in major differences in disease severity remains to be seen. In contrast, tillage, which is considered to be a negative driver of Rhizoctonia spp. soil accumulation, was not found to be significant in our study. It is possible that tillage can be over-ridden by environmental factors in short-term studies such as ours. In a previous study, $R$. solani was substantially reduced by tillage, whereas $R$. oryzae was not (33). The meteorological and soil texture factors used in this study explained $<50 \%$ of the total of the variation, indicating that unaccounted factors were contributing to residual variation. These might include biotic factors such as crop cultivar or rhizosphere community structure. Taken together, the survey findings suggest that planting risks for growers will vary depending upon their location and whether $R$. solani AG8 is present in the soil. For instance, direct seeding in high-risk areas such as Lind and Connell are predicted to be more conducive to diseases caused by $R$. solani AG8 compared with Pullman and Colton, and growers in the former areas should consider seed treatments, green bridge control, and seed opener disturbance during planting as means of minimizing risk.

Finally, plant diseases are expected to be affected by climate changes (11). The affect of climatic factors on the frequency and distribution of Rhizoctonia root rot pathogens is unknown. However, our survey and other studies will provide a baseline for future disease forecasts, and fill a knowledge gap in this type of data (36), which is especially lacking for the soilborne microbes (2).

\section{ACKNOWLEDGMENTS}

This work was funded by grants 3019-3019-4564 (P. A. Okubara) and 3019-3564 (P. A. Okubara and T. C. Paulitz) from the Washington Grain Commission, United States Department of Agriculture (USDA) Agricultural Research Service Project Number 5248-22000-012-00D (P. A. Okubara and T. C. Paulitz), and USDA NIFA Regional Approaches to Climate Change (REACCH). We thank A.-M. Fortuna and B. Landa for training in SAS, D. Poudyal-Sharma for help with JMP, J. Parejko for guidance on the use of ArcMap, J. Burns and his group for access to WSU Variety Testing sites, N. Walter for assistance with soil extractions, and 11 Washington state grower-cooperators for the use of their parcels. References to a company or product by the United States Department of Agriculture (USDA) are only for the purposes of information and do not imply approval or recommendation of the product to the exclusion of others that may also be suitable. USDA is an equal opportunity employer.

\section{LITERATURE CITED}

1. Abatzoglou, J. T. 2013. Development of gridded surface meteorological data for ecological applications and modelling. Int. J. Climatol. Online publication. doi:10.1002/joc.3413

2. Chakraborty, S., Pangga, I. B., and Roper, M. 2012. Climate change and multitrophic interactions in soil: the primacy of plants and functional domains. Global Change Biol. 18:2111-2125.

3. Cook, R. J. 1990. Diseases caused by root-infecting pathogens in dryland agriculture. Adv. Soil Sci. 13:215-239.

4. Cook, R. J. Schillinger, W. F., and Christensen, N. W. 2002. Rhizoctonia root rot and take-all of wheat in diverse direct-seed spring cropping systems. Can. J. Plant Pathol. 24:349-358.

5. Douglas, C. L., Jr., Rickman, R. W., Klepper, B. L., Zuzel, J. F., and Wysocki, D. J. 1992. Agroclimate zones for dryland winter wheat producing areas of Idaho, Washington, and Oregon. Northwest Sci. 66:26-34.

6. Gill, J. S., Sivasithamparam, K., and Smettem, K. R. J. 2000. Soil types with different texture affects development of Rhizoctonia root rot of wheat seedlings. Plant Soil 221:113-120. 
7. Gill, J. S., Sivasithamparam, K., and Smettem, K. R. J. 2001. Effect of soil moisture at different temperatures on Rhizoctonia root rot of wheat seedlings. Plant Soil 231:91-96.

8. Gill, J. S., Sivasithamparam, K., and Smettem, K. R. J. 2001. Soil moisture affects disease severity and colonization of what roots by Rhizoctonia solani AG-8. Soil Biol. Biochem. 33:1363-1370.

9. Google Inc. 2009. Google Earth (Version 5.1.3533.1731) (software). Google Inc., Mountain View, CA.

10. Kandel, S. L., Smiley, R. W., Garland-Campbell, K., Elling, A., Abatzoglou, J., Huggins, D., Rupp, R., and Paulitz, T. Relationship between climatic factors and distribution of Pratylenchus spp. Plant Dis. 97:1448-1456.

11. Luck, J., Spackman, M., Freeman, A., Trebicki, P., Griffith, W., Finlay, K., and Chakraborty, S. 2011. Climate change and diseases of food crops. Plant Pathol. 60:113-121.

12. MacNish, G. C., and Neate, S. M. 1996. Rhizoctonia bare patch of cereals: an Australian perspective. Plant Dis. 80:965-971.

13. Mavrodi, D. M., Parejko, J. A., Mavrodi, O. V., Kwak, Y., Weller, D. M., Blankenfeldt, W., and Thomashow, L. S. 2013. Recent insights into the diversity, frequency and ecological roles of phenazines in fluorescent Pseudomonas spp. Environ. Microbiol. 15:675-686.

14. Mazzola, M., Wong, O. T., and Cook, R. J. 1996. Virulence of Rhizoctonia oryzae and $R$. solani AG-8 on wheat and detection of $R$. oryzae in plant tissue by PCR. Phytopathology 86:354-360.

15. Ogoshi, A., Cook, R. J., and Bassett, E. N. 1990. Rhizoctonia species and anastamosis groups causing root rot of wheat and barley in the Pacific Northwest. Phytopathology 80:784-788.

16. Okubara, P. A., Li, C., Schroeder, K. L., Schumacher, R. T., and Lawrence, N. P. 2007. Improved extraction of Rhizoctonia and Pythium DNA from wheat roots and soil samples using pressure cycling technology. Can. J. Plant Pathol. 29:304-310.

17. Okubara, P. A., Schroeder, K. L., and Paulitz, T. C. 2008. Identification and quantification of Rhizoctonia solani and $R$. oryzae using real-time polymerase chain reaction. Phytopathology 98:837-847.

18. Otten, W., and Gilligan, C. A. 2006. Soil structure and soil-borne diseases: using epidemiological concepts to scale from fungal spread to plant epidemics. Eur. J. Soil Sci. 57:26-37.

19. Otten, W., Harris, K., Young, I. M., Ritz, K., and Gilligan, C. A. 2004. Preferential spread of the pathogenic fungus Rhizoctonia solani through structured soil. Soil Biol. Biochem. 36:203-210.

20. Pan, Z., Yang, X. B., Pivonia, S., Xue, L., Pasken, R., and Roads, J. 2006. Long-term prediction of soybean rust entry into the continental United States. Plant Dis. 90:840-846.

21. Parejko, J. A., Mavrodi, D. M., Mavrodi, O. V., Weller, D. M., and Thomashow, L. S. 2013. Taxonomy and distribution of phenazineproducing Pseudomonas spp. in the dryland agroecosystem of the inland Pacific Northwest, United States. Appl. Environ. Microbiol. 79:38873891.

22. Paulitz, T. C. 2002. First report of Rhizoctonia oryzae on pea. Plant Dis. $86: 442$.

23. Paulitz, T. C. 2006. Low input no-till cereal production in the Pacific
Northwest of the US: the challenges of root diseases. Eur. J. Plant Pathol. 115:271-281.

24. Paulitz, T. C., Okubara, P. A., and Schroeder, K. L. 2009. Integrated control of soilborne pathogens of wheat. Pages 229-245 in: Recent Developments in the Management of Plant Diseases, Plant Pathology in the 21st Century. U. Gisi, I. Chet, and M. L. Gullino, eds. Springer, New York.

25. Paulitz, T. C., and Schroeder, K. L. 2005. A new method for quantification of Rhizoctonia solani and R. oryzae from soil. Plant Dis. 89:767-772.

26. Paulitz, T. C., Schroeder, K. L., and Schillinger, W. F. 2009. Root diseases of cereals in an irrigated cropping system: effect of tillage, residue management and crop rotation. Plant Dis. 94:61-66.

27. Paulitz, T. C., Smiley, R. W., and Cook, R. J. 2002. Insights into the prevalence and management of soilborne cereal pathogens under direct seeding in the Pacific Northwest, U.S.A. Can. J. Plant Pathol. 24:416-428.

28. Paulitz, T. C., Zhang, H., and Cook, R. J. 2003. Spatial distribution of Rhizoctonia oryzae and Rhizoctonia root rot in direct-seeded cereals. Can. J. Plant Pathol. 25:295-303.

29. Pietravalle, S., Shaw, M. W., Parker, S. R., and van den Bosch, F. 2003. Modeling of relationships between weather and Septoria tritici epidemics on winter wheat: a critical approach. Phytopathology 93:1329-1339.

30. Poole, G. J., Smiley, R. W., Walker, C., Huggins, D., Rupp, R., Abatzoglu, J., Garland-Campbell, K., and Paulitz, T. C. 2013. Effect of climate on the distribution of Fusarium spp. causing crown rot of wheat in the Pacific Northwest of the United States. Phytopathology 103:1130-1140.

31. Schillinger, W. F., and Papendick, R. I. 2008. Then and now: 125 years of dryland wheat farming in the Inland Pacific Northwest. Agron. J. 100:S166-S183.

32. Schroeder, K. L., Okubara, P. A., and Paulitz, T. C. 2007. Geographic distribution of Rhizoctonia and Pythium species in soils from dryland cereal cropping systems in eastern Washington. Phytopathology 97:S105.

33. Schroeder, K. L., and Paulitz, T. C. 2006. Root diseases of wheat and barley during the transition from conventional tillage to direct seeding. Plant Dis. 90:1247-1253.

34. Schroeder, K. L., and Paulitz, T. C. 2008. Effect of inoculum density and soil tillage on the development and severity of Rhizoctonia root rot. Phytopathology 98:304-314.

35. Sharma-Poudyal, D., and Chen, X. M. 2011. Models for predicting potential yield loss of wheat caused by stripe rust in the U.S. Pacific Northwest. Phytopathology 101:544-554.

36. Shaw, M. W., and Osborne, T. M. 2011. Geographical distribution of plant pathogens in response to climate change. Plant Pathol. 60:31-43.

37. Weller, D. M., Cook, R. J., MacNish, G., Bassett, E. N., Powelson, R. L., and Petersen, R. R. 1986. Rhizoctonia root rot of small grains favored by reduced tillage in the Pacific Northwest. Plant Dis. 70:70-73.

38. Yin, C., Hulbert, S. H., Schroeder, K. L., Mavrodi, O., Mavrodi, D., Dhingra, A., Schillinger, W. F., and Paulitz, T. C. 2013. The role of bacterial communities in the natural suppression of Rhizoctonia bare patch of wheat (Triticum aestivum L.). Appl. Environ. Microbiol. 79:1728-1738. 